\section{AUTOR}

Carlos Javier

Castro Brunetto*

carbrunetto@

gmail.com

* Profesor titular de

Departamento de Historia

del Arte y Filosofía de la

Universidad de la Laguna

\title{
Las devociones marianas españolas en el Brasil colonial
}

\author{
As devoções marianas espanholas no Brasil colonial \\ Spanish Marian devotions in colonial Brazil
}

\section{RESUMEN}

El objetivo de este artículo es analizar la presencia de las devociones españolas de la Virgen María y su arraigo en diversas regiones de Brasil, un tema poco conocido en el ámbito de la historia religiosa y cultural del país. Estudiaremos su implantación, amparándose en el origen devocional español y cómo encontraron vías de expresión espiritual y artística en el seno de la sociedad colonial brasileña.

\section{RESUMO}

O objetivo deste artigo é avaliar a presença das devoções espanholas da Virgem Maria e sua fixação em várias regiões do Brasil, uma temática pouco conhecida no âmbito da história religiosa e cultural do país. Estudaremos sua implantação, sob a base da origem devocional espanhola e as vias de expressão espiritual e artística ao abrigo da sociedade colonial brasileira.

\section{ABSTRACT}

The aim of this paper is to analyze the presence of Spanish devotions of the Virgin Mary and their roots in several Brazilian regions. This presence has been an unexplored field in the religious and cultural history of the country. We will be studying its implementation regarding the devotional Spanish origin and how they have found ways of spiritual and artistic expressions within the Brazilian colonial society. 


\section{La cuestión mariana en Brasil como hecho social}

Los historiadores que con curiosidad se aproximen a la cultura y evolución del pensamiento religioso brasileño apreciarán con el tiempo algunas características que distancia a Brasil de su metrópoli, caso de la inesperada influencia española en la piedad y arte de la colonia. Mientras las devociones hispanas en el tiempo de los Reyes Católicos, en constante defensa del dogma de la Inmaculada Concepción, tenían a María como insignia del catolicismo que querían introducir en América, los súbditos del rey de Portugal tuvieron otro protagonista casi absoluto para las tierras del Brasil: el nombre de Cristo. Lo cierto es que en España, el protagonismo de la Virgen se alzó de forma extraordinaria a partir de la constitución Cum praeexcelsa proclamada por Sixto IV, en el que se insiste en la importancia de haber sido "la habitación de su Unigénito" (Denzinger, 1963: 216). Es decir, que ese pontífice planteaba ya, sin ambigüedades, la necesidad de proclamar el dogma de la concepción inmaculada de la Virgen. La cuestión, tratada en el concilio de Trento y reforzada por la bula Sollicitudo ómnium de 1661, dada por el papa Alejandro VII (Denzinger, 1963: 297), tuvo la acogida y el especial fervor de los españoles, incentivado, qué duda cabe, por los Reyes Católicos. Julio Caro Baroja, antropólogo e historiador, en su obra clásica Las formas complejas de la vida religiosa. Religión, sociedad y carácter en la España de los siglos XVI y XVII, cuya primera edición es de 1978, nos advierte de que si en España y en ese tiempo tuvo mayor eco destacar a María que a la propia ciencia, ha sido por vocación y no por imposiciones. De hecho, señala que "el historiador hará bien en considerarlo como un hecho social antes que ponerse a opinar si es un hecho bueno o malo" (Caro Baroja, 1985: 49).

Otros especialistas han querido desvelar la vertiente profundamente mariológica de España desde los años finales del siglo XV. Santiago Sebastián apunta, sin dudarlo, que una tendencia espiritual, a la par que política, fue la utilización de María como figura esencial para combatir a los luteranos y el resto de las reformas del Quinientos: "Precisamente como reacción a los errores de la Reforma, los teólogos españoles reconocieron en la Virgen una virtud que tuvo en tiempos lejanos: María como vencedora de las herejías" (Sebastián, 1985: 195). Estas hipótesis nos llevan a comprender a María no solo como una cuestión religiosa, sino como un asunto de Estado. Con Portugal se comparte el fervoroso deseo de la proclamación del dogma de la Inmaculada y la lúcida presencia de María en la vida espiritual, pero ambos países divergen en la necesidad política de la Virgen como argumento político e incluso racial y cultural: María como definición de la nueva identidad política española nacida hacia 1500 .

Así pues, entre España y Portugal no sugerimos que existiese una diferencia esencial en los fundamentos de la Fe, sino que la cristología, la exaltación de Cristo, fue el pilar en los primeros momentos de la evangelización de Brasil, frente a las arraigadas preferencias populares marianas de los españoles, amparadas en las ideas antes expuestas. Este planteamiento podría apoyarse en dos hechos: por un lado, que si en Brasil el cristianismo fue introducido con fuerza por los misioneros jesuitas, soldados de Cristo, y por un débil clero secular, en la América hispana el rigor de dominicos y franciscanos, tan marianos, subrayaron esa inclinación devota por la Virgen (a la par que por Cristo, claro). El segundo hecho es que los lusitanos encontraron pueblos indígenas con una cultura más dispersa, animista y por lo que parece, con un escaso desarrollo teológico. De esta manera, fue relativamente más fácil neutralizar el poder y pensamiento de los tupís de la costa y los guaranís del sur, más fácil para los portugueses, pero traumático para los indígenas ${ }^{1}$. Sin embargo, las elevadas culturas de la América central y andina requirieron una persuasión mayor que incluía la sacralización de las figuras maternales y divinas de los cultos precolombinos por la omnipresencia de la Virgen María y, lógicamente, de Dios.

Sin embargo, ninguna de estas cuestiones fue considerada en los orígenes religiosos del Brasil. La Virgen y su advocación, siendo central en la doctrina romana, no fue una herramienta tan decisiva para la evangelización brasileña, tal y como se desprende de la acción misionera y eclesial de los primeros momentos, sobre todo tras la llegada de la Compañía de Jesús en 1549. Es decir, que en 
la estrategia religiosa, María ocupó el lugar que le corresponde en la sensibilidad de la Iglesia, sin que fuese necesario reforzar su papel para sustituir a diosas locales indígenas, de modo que las promesas de la redención y el conjunto de la doctrina era el objetivo de los misioneros, que centraban en Cristo y el mensaje evangélico la mayor parte de su atención.

Una vez establecidos los colegios jesuíticos, María ocupó un papel relevante: como señala Serafim Leite, el gran estudioso de las misiones de la Compañía en Brasil "De todas as devoções do século XVI no Brasil entre os índios e nos Colégios, a mais apta para formar a piedade foi, sem dúvida, a de Nossa Senhora" (Leite, 2004: 330). Pese a todo, las devociones marianas llegadas a Brasil en el siglo $\mathrm{XVI}$ eran las portuguesas, como es lógico, pero es que en el siglo XVIII continuaba siendo igual, es decir, que prácticamente no surgieron "Marías" de Brasil, salvo las excepciones que vamos a presentar en este trabajo.

En la metrópoli, el papel asignado a la Virgen en la piedad popular era muy similar al que representaba en España. Cualquier libro piadoso publicado en Portugal entre los siglos XVI y XVIII nos alerta sobre su función como salvadora de "la nación portuguesa". Como ejemplo citamos un trecho del sermón de Antônio Pereira da Câmara, de 1757, dedicado a Nossa Senhora da Lapa con motivo de la fundación del convento de clarisas de la Imaculada Conceição de Río de Janeiro, en el que se recordaba su acción protectora salvando las almas de los justos con motivo del terrible terremoto de Lisboa sucedido en 1755:

(...) O sucesso de Lisboa, que tanto nos tem magoado os coraçõens, a muyta distancia em que vivemos, acredita a nossa dor; pois não faltou já quem dicesse em cazo semelhante que a dor na prezensa reparte-se na alma; acrecentando que a dor na precenza tem a mesma precenza por alivio, e a dor na ausência hé todo dor. O dito basta para saber Portugal o que deve às suas conquistas (...) differensa na grande multidaõ dos que pereceraõ a estragos de taõ formidável, e rigorozo castigo, como he certo veriamos, que os devotos da Virgem Maria todos se salvaraõ, e que só se condenaraõ com irremediável desgraça os que naõ eraõ seus devotos (Câmara, 1757:15).

Este texto ofrece una imagen nítida de protección sobre la vida portuguesa, porque la muestra como mediadora entre la vida y la muerte en casos de infortunios. El autor añade que el dolor sentido por lo acaecido en la corte aumentó "a muyta distancia em que vivemos", es decir, que el sentimiento lusitano sitúa a Brasil como parte indivisible de Portugal y sus tradiciones. Al fin y al cabo, el auditorio de este sermón lo conformaban brasileños de Río de Janeiro que inauguraban un convento de clarisas con religiosas venidas del convento de Nossa Senhora do Desterro de Salvador da Bahia, es decir, que toda la historia transcurría en territorio brasileño y a las élites brasileñas gustaba sentirse lusitanas.

Brasil no fue un país de milagros y apariciones, ni existió el deseo de sincretizar: simplemente, los pueblos indígenas fueron dominados y sometidos a la esclavitud sin un corpus legal que, al menos en el papel, les protegiese, como aconteció con los indios de España desde la aprobación de las Leyes de Burgos de 1512 y luego de las Leyes Nuevas de 1542. De hecho, el único texto que plantea una somera protección fue el Regimento de 1570 que proclamaba como causa para la esclavización del indio cualquier acontecimiento que motivase la guerra justa, lo que significa, en la práctica, la bendición del Estado en todo lo relacionado con la captura de indios para la protección de la colonia (Siqueira, 2004: 171). Los jesuitas, únicos defensores de los indígenas brasileños y por ello con numerosos enemigos en la corte, sí que acudieron a la Virgen María como protectora de muchas de las misiones fundadas en el litoral y la región de São Paulo, pero solo en su ministerio de Madre de Dios, sin otras connotaciones como las antes aducidas.

Solo encontramos atisbos de una religiosidad mariana específicamente brasileña en la imagen de Nossa Senhora Aparecida. Hallada una pequeña pieza de barro en 1717, cuyo estilo coincide con las primeras manifestaciones artísticas de la escultura brasileña, aún vinculadas al gótico tardío de influencia flamenca, comenzó a ganar el fervor popular como hacedora de milagros, pero solo en 1930 fue declarada patrona del Brasil. No hubo en este caso una aparición, sino el hallazgo fortuito 
de una escultura de barro abandonada en el lecho del río Paraíba do Sul (São Paulo), es decir, que los orígenes devocionales son toscos, aunque luego creciese el fervor por la imagen, que contó con una capilla desde 1745 hasta la construcción de la actual basílica, ya en el siglo XX².

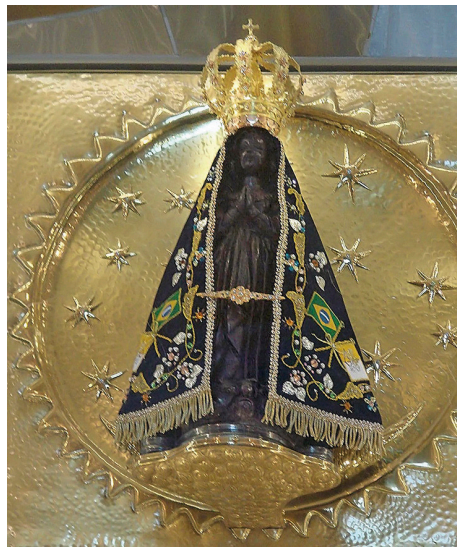

Imagen 1. Nossa Senhora Aparecida. Anónima. Imagen de barroco cocido, c. 1717. Santuário de Aparecida, Estado de São Paulo.

\section{Los primeros nombres de María en tierras brasileñas}

Desde 1500 este territorio, entonces conocido como Terra de Santa Cruz, estuvo en manos de exploradores y aventureros, además de algún misionero aislado, a diferencia de la América hispana, entregada a la idea colonizadora y evangelizadora. Dicho de otro modo, que la devoción a la Cruz como símbolo absoluto del cristianismo se impuso por encima de cualquier otra devoción popular de la época. Este argumento, que a simple vista no parece relevante, lo es si consideramos que hacia 1500 Portugal vivía momentos de gloria gracias a su expansión oceánica; apelar a San Vicente, Santa María de la Victoria o Santo António adquiría un valor político insospechado pues aludía a los éxitos de la lusitanidad, más allá de un sencillo requerimiento o auxilio religioso.

Sin embargo, la parroquia más antigua de la colonia fue la de Nuestra Señora de la Asunción, en São Vicente, litoral del actual estado de São Paulo, y Gonçalo Monteiro fue su primer párroco (Rubert, 1992:65-68). La preponderancia del clero secular en las nuevas tierras brasileñas se explica por la crisis del monacato portugués a comienzos del siglo XVI, la ruina de muchos monasterios históricos, sobre todo del norte lusitano y la escasez de monjes que justifica, en parte, el atraso de la evangelización de Brasil por los regulares, como demuestra José Marques (1991:45-63). Siendo la Cruz un símbolo general del cristianismo, predilecta en las hazañas de conquista de la corona lusitana y de la vida seglar, no es de extrañar su notoriedad en la más temprana religiosidad colonial, por encima de las devociones marianas, tan asociadas a las formas devocionales de las órdenes religiosas.

La erección de la primera diócesis, bajo el título de San Salvador, en Salvador da Bahia, aconteció en 1551 y su primer obispo, D. Pedro Fernandes, apodado "Sardinha", como sus sucesores tuvieron muy claro que en Brasil debía reproducirse el modelo de espiritualidad que habían aprendido en los seminarios de Portugal.

En los centros urbanos y haciendas habitaban los portugueses y una mano de obra indígena que fue progresivamente esclavizada. Por ello, responder en todo al modelo metropolitano era una necesidad de arraigo, no con relación a la colonia, sino con respecto a la metrópoli, abandonada por seguir un futuro incierto en los trópicos. Las formas de vida religiosa y las devociones fueron las metropolitanas. Otra cosa fue la acción de los jesuitas, comandados por el P. Manuel da Nóbrega, primer provincial de la Compañía en Brasil, seguido por una pequeña pero eficaz saga de sacerdotes y hermanos, entre ellos cabe destacar al tinerfeño José de Anchieta (Viotti,1980: 67-68)33, siendo los jesuitas quienes mejor contribuyeron desde el primer momento a reforzar el papel de la Virgen en la naciente sociedad.

A partir de la década de 1580 la orden franciscana comenzaría un exhaustivo proceso de asentamiento en los núcleos urbanos. Se organizó como custodia de Santo Antônio do Brasil desde 1584, con sede en Salvador da Bahia, y se fundó el primer convento, el de Nossa Senhora das Neves, en Olinda (Pernambuco) el año 1585. En 1657 esta custodia, con numerosos conventos abiertos por todo el litoral entre Pernambuco y São Paulo, fue elevada a provincia; en 1659 se creó en Río de Janeiro la custodia de la Imaculada Conceição, que 
atendía la vida espiritual franciscana de Espírito Santo, Río de Janeiro y São Paulo, a la vez que reglaría la presencia de terciarios franciscanos en Minas Gerais, Goiás y Mato Grosso durante el siglo XVIII. Finalmente, en 1675 esta custodia se convirtió en la provincia franciscana de la Imaculada Conceição (Castro Brunetto, 1996: 52).

No podemos concluir este apartado sin hacer mención a dos episodios relacionados con la Virgen María y la presencia de españoles durante los primeros años de la colonización que generaron una abundante literatura durante los siglos XVII y XVIII hasta transformase en leyendas e imágenes de la brasilidad.

La primera historia peculiar es la fundación de la ermita de Nossa Senhora da Penha en Vila Velha, Espírito Santo, por devoción de fray Pedro Palacios, en 1558. Este fraile castellano es el protagonista de la leyenda que pondría bajo los focos a esa peña, vecina a la ciudad de Vitória. Su vocación de eremita, dedicado a la oración y la contemplación de los misterios divinos y en especial del ejemplo de María, le convertiría en el principal introductor del culto mariano en la región. Con el tiempo, la creación de un eremitorio, luego convertido en convento franciscano de gran importancia, quedaría fuertemente ligado a una visión mística de la Virgen; no es aleatoria la elección de una peña, realmente un peñasco, para la edificación de la primera capilla en la ladera y luego en la cima, ya que era un proceso de sacralización muy común desde finales de la Edad Media (Bahiense, 1952: 35 41); no obstante, contar con un espacio sacralizado es poco común en la historia religiosa de Brasil. La leyenda no habla de una aparición de la Virgen, sino que un cuadro con su efigie que Palacios había traído desde España, había sido elevado hasta lo alto de la peña en dos ocasiones por los ángeles, lo que sin duda remitía a la voluntad de la Virgen por recibir el culto en la cima de la montaña, un recurso frecuente en los milagros y apariciones divinas desde el libro del Génesis.

Será en los primeros años del siglo XX cuando se lleve a cabo la ejecución de un conjunto de lienzos sobre la vida de fray Pedro Palacios, colgados en el convento de Vila Velha. Estas pinturas, ejecutadas por el pintor Benedito Calixto (1853-1927), quien frecuentó el género de historia aprendido en

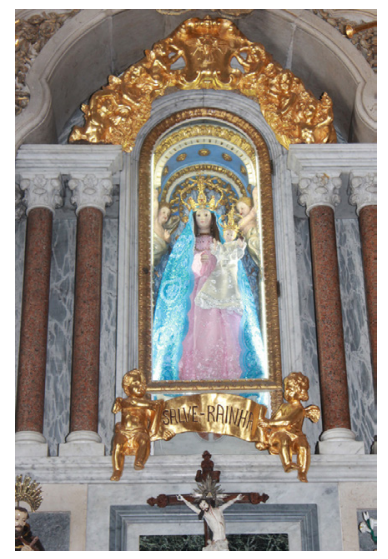

Imagen 2. Nossa Senhora da Penha. Anónima. Imagen de talla y vestida. Siglos XVII-XVIII. Convento de Nossa Senhora da Penha, Vila Velha, Espírito Santo

París y luego ejercitado especialmente en São Paulo, suponen uno de los mejores ciclos sobre los primeros momentos de la historia brasileña y el fervor mariano. Aunque la historiografía crítica señale a Calixto como uno de los pintores que negaron la modernidad llegada a Río en aquellos años (Gonçalves, 2007: 43-44), no podemos negar su valor profundamente historicista, como el lienzo firmado el año de su muerte, 1927, en el que el Padre Palacios muestra el hallazgo de la Virgen de la Peña.

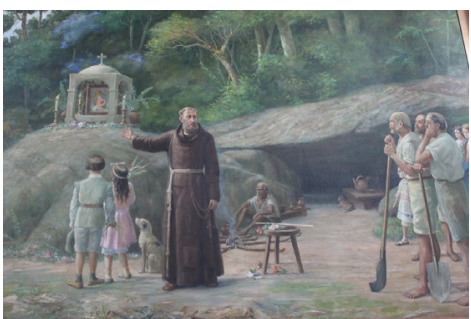

Imagen 3. El Padre Palacios muestra el hallazgo de la Virgen de la Peña. Benedito Calixto. Lienzo firmado y fechado en 1927. Convento de Nossa Senhora da Penha, Vila Velha, Espírito Santo

Por último, hemos de destacar al jesuita José de Anchieta (1534-1597) Ilamado el "Apóstol del Brasil", fundador de la alta cultura brasileña, primer gramático de la lengua tupí, autor de numerosa obra literaria (sermones, poemas, autos sacramentales, epístolas con el fin de narrar los acontecimientos de la orden jesuítica, etc...) y, por supuesto, uno de los misioneros más activos del siglo XVI. Con relación a María, a quien dedicó toda su obra misionera, es la protagonista de un episodio biográfico. Anchieta quedó como rehén de los indios tamoios en el litoral norte de São Paulo, en la zona de Iperoig 
(hoy Ubatuba), mientras el provincial, Manuel da Nóbrega, negociaba una paz entre dos bandos; por un lado la llamada confederação dos tamoios, anticristiana, y por otro, la alianza de los indios tupiniquins con los portugueses. Según narrase el propio Anchieta, en muchas ocasiones salvó su vida ante los temibles tamoios gracias a las oraciones dirigidas a la Virgen María, quien le respondió protegiéndole. Durante su prisión en Iperoig en 1563 concebiría una de sus obras literarias más ambiciosas, el poema titulado De Beata Virgine Dei Matre Maria, luego redactada en São Vicente entre 1563 y 1565, pero publicada en 1663 por el Padre Simão de Vasconcelos (González Luis, 1988: 114).

Desde un punto de vista práctico, Anchieta reconoce en la dedicatoria haber imaginado este poema durante su cautiverio: "Aquí tienes, Madre Santísima, los versos que te prometí en otro tiempo, rodeado de enemigos feroces/ Cuando mi presencia amansaba a los fuertes tamoyos, y negociaba, inerme, las paces/ (...)" (Anchieta, 1987: 269). Aunque su autor en ningún momento haya sugerido haberlo escrito sobre las arenas de la playa de Iperoig, memorizarlo completamente y luego redactarlo en São Vicente, una hazaña fuera de toda lógica, así fue sugerido y escrito por sus biógrafos, generando la leyenda de que Anchieta recibió la gracia de memorizar todos los versos. Lo piadoso y devocional se cruzaron una vez más en el camino de la verdad.

Este acontecimiento animó la realización de varias obras artísticas desde finales del siglo XIX, en el periodo de afirmación de la República fundada en 1889, que buscaban en las epopeyas históricas el sustento ideológico de la Nación. En ese contexto

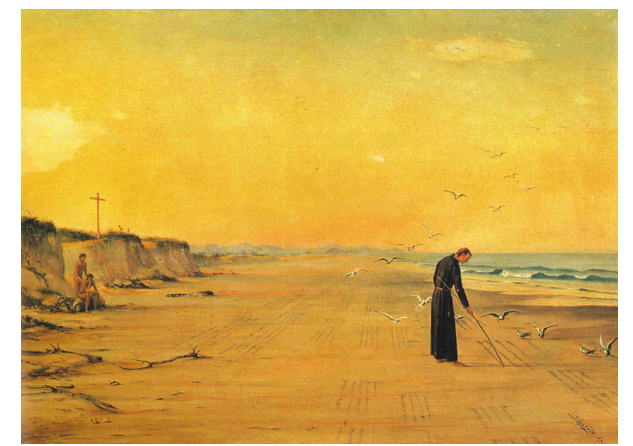

Imagen 4. Anchieta escribe el Poema Mariano en la playa de Iperoig. Benedito Calixto, óleo sobre lienzo, 1901. Colégio de São Luís. São Paulo. se entiende el célebre lienzo de Benedito Calixto, de 1901 (Colégio de São Luís, São Paulo), donde Anchieta, empleando un palo, redacta sobre la arena fresca el poema mariano, alimentando ese mito, que se vio reforzado por la más conocida obra de este tema, conservada en la colección del Banco Itaú y pintada por Cândido Portinari, uno de los máximos exponentes del modernismo y las vanguardias brasileñas (Fadel, 2006: 87-91). En el lienzo optó por formas artísticas y compositivas cercanas al Expresionismo para mostrar a Anchieta aislado, absorto en la redacción del poema que se convertiría en una de las primeras obras literarias redactadas en Brasil.

\section{El protagonismo español y el culto brasileño}

A comienzos del siglo XVII las devociones marianas continuaron la religiosidad portuguesa de su tiempo. El clero secular fomentaría desde la diócesis de Salvador y luego desde la prelatura de Río de Janeiro, transformada en diócesis plena en 1676, el culto a la Virgen bajo las advocaciones más comunes, destacando Nossa Senhora da Ajuda (de la Ayuda, relacionado con las Vírgenes de Pasión), Nossa Senhora da Graça (de la Gracia o Milagros), Nossa Senhora da Piedade (de la Piedad, que se convertiría en la principal devoción relacionada con el Triduo Pascual), Nossa Senhora da Assunção (de la Asunción) y otras devociones puntuales. Sin embargo, destaca por encima de todas la devoción a la Imaculada Conceição y a tres nombres directamente relacionados con la espiritualidad española: Nossa Senhora do Pilar (con alusiones expresas a su aparición en Zaragoza ante el Apóstol Santiago), Nossa Senhora do Monte-Serrate (derivada del culto a la Virgen de Montserrat fomentada por los benedictinos) y Nossa Senhora da Candelária (cuyo culto se inició en Río de Janeiro relacionado con la patrona de Tenerife, y desde allí se expandió por el resto de Brasil). Esa predilección por devociones españolas desde época temprana en una colonia ajena a la expansión hispana resulta extraña, y no ha llamado la atención de los historiadores, algo más extraño aún. Si bien es cierto que España y Portugal compartían 
preocupaciones religiosas similares (como la defensa de la concepción inmaculada de María o la defensa del dogma eucarístico) y usos litúrgicos comunes, también es cierto que, aparentemente, sería lógico que la mentalidad popular prefiriese en Brasil el favor de las devociones populares marianas portuguesas. Por eso es peculiar la irrupción de esos cultos hispanos, que no fueron llevados a la colonia por españoles, sino por lusitanos. En este capítulo intentaremos abordar y solventar, en lo posible, esta encrucijada histórica.

Por su importancia, hemos de comenzar por el culto a la Inmaculada Concepción. La defensa de este ansiado dogma se convirtió en Portugal, al igual que en España, en un asunto de Estado. Los monarcas a lo largo del siglo XV fueron considerando cada vez más esta devoción en su patrocinio, que quedó unido al derecho de Padroado. Como sabemos, El Padroado es un conjunto de leyes y normas de naturaleza jurídica y administrativa que los pontífices concedieron a los reyes de Portugal entre 1452 y 1534, especialmente dirigidas a los derechos eclesiásticos que los monarcas tendrían en los territorios ultramarinos que conquistasen y en los que extendiesen la fe romana. En lo que afecta a la piedad brasileña, el breve Dudum pro parte otorgado por León $\mathrm{X}$ el 31 de marzo de 1516, confería a los reyes portugueses el derecho universal de Padroado en todos sus dominios, que comprendía: proponer a los beneficiados eclesiásticos, incluyendo los episcopales; conservar y reparar las iglesias, monasterios y otros lugares píos de las diócesis; dotar a templos y monasterios de los objetos necesarios para el culto; mantener a los eclesiásticos y seculares adscritos al servicio religioso y fomentar el número de clérigos suficientes para el culto (Oliveira, 1994, p. 139).

Flávio Gonçalves ha estudiado la importancia que las constituciones sinodales portuguesas otorgaron entre 1565 y mediados del siglo XVIII a la representación de las imágenes, como consecuencia directa de la influencia del derecho en la religiosidad y el arte; por otro lado, este prestigioso iconógrafo portugués afirma que los dos cultos con trascendencia artística impuestos desde la segunda mitad del siglo en Portugal, y se entiende que en sus colonias, fueron la Inmaculada Concepción y las Ánimas del Purgatorio:

\begin{abstract}
A doutrina da Imaculada Conceição, propagada pelo mundo católico pelos franciscanos e jesuitas, ganhou uma estraordinária força no decorrer da segunda metade do século XVI e da primeria metade do século imediato. Irracionalista, a Espanha aderiu calorosamente à nova devoção (...). Em Portugal, ao tempo tributário da cultura espanhola, logo em fins de 1644 D. João IV escolheu a Virgem da Imaculada Conceição para padroeira do reino, ratificando uma escolha já feita pelo clero e fiéis (...). Nos fins do século XVI, e durante o século XVII, os nossos artistas adoptaram para a Imaculada Conceição os modelos dos mestres espanhóis e italianos (Gonçalves, 1973: 17).
\end{abstract}

$\mathrm{Si}$ bien los primeros historiadores religiosos brasileños, ya en el siglo XVII, citaban con detalle todos los hechos de la conquista y fundación de ciudades y conventos, no se detuvieron especialmente en cuestiones relacionadas con el fomento al culto mariano, como es el caso del franciscano bahiano frei Vicente do Salvador (c. 1564-c. 1639), autor del manuscrito História do Brasil datado en 1627 aunque sólo publicado en 1888. En este libro, de naturaleza positivista, narra los hechos acaecidos a lo largo de ese tiempo, pero no se refiere a datos devocionales específicos, tal vez por dar por sentado que no podía haber otro culto oficial que el de la Inmaculada y que el resto de las advocaciones respondían, simplemente, a devociones particulares de los fundadores de las capillas o los conventos.

Este mismo sentimiento lo advertimos en todos los libros publicados en los siglos siguientes, como los sermones del jesuita Padre Antônio Vieira (16081697), nacido en Lisboa pero formado en el colegio de Salvador, verdaderos cantos a la independencia de la corona portuguesa tras la Restauración de 1640 y a todos los valores propios de la lusitanidad, entre ellos la defensa de los santos portugueses y de María como luz de Portugal bajo el nombre de la Inmaculada Concepción (Paiva, 1997: 103-105).

Ese autory todos los que le antecedieron y siguieron, resaltaban la trascendencia de las formas retóricas con el fin de obtener la preeminencia absoluta de lo religioso sobre lo mundano. Siguiendo la estructura de los "diálogos", característico método 
literario quinientista llegado hasta el Barroco, frei Apolinario da Conceição, religioso de la provincia de la Inmaculada de Brasil, aunque nacido en Lisboa, en su obra Viagem devota, e feliz... (1746), dedica el diálogo $V$ a reflexionar sobre la "verdadera devoción", haciendo de la reverencia uno de los actos más importantes para la veneración de Cristo, María y los santos. En sus palabras:

Consiste pois a verdadeira devoção, fallando genéricamente, em tres cousas principalmente que são Reverencia, Invocação, e Imitação. A reverencia pertence fazer estimação, e apreço da pessoa e excellencias do Santo a quem somos devotos (...) Porém não havemos de contentarnos com isto, senão que também havemos de dar mostras exteriormente, da estimação, que fazemos em o interior. $E$ isto se faz reverenciando seu nome, sua Imagem, sua doutrina, suas palavras, suas reliquias. A Invocação pertence offerecelhe fervorosos desejos, orações devotas, e outras cousas semelhantes a estas (Conceição, 1746: 143144).

La defensa de las imágenes como vehículo cierto para la transmisión de la fe, fue una constante en las culturas ibéricas de finales del siglo XVI y durante todo el tiempo barroco. Es un proceso similar al vivido en la literatura, donde las artes de la oratoria desplegadas en los sermones complementaban la imagen visual: es decir, que la estampa grabada en un libro piadoso, el cuadro de un oratorio particular o iglesia, o la escultura devocional que podría salir en procesión, tenía el mismo valor que la palabra.

En cuanto a las representaciones de la Inmaculada Concepción en el siglo XVII brasileño, casi todas responden al esquema tradicional ibérico, es decir, con las manos juntas sobre el pecho y la media luna a los pies, en muchas ocasiones con cabezas de querubines bajo esa media luna. La mayoría de las piezas conservadas son de pequeño tamaño, normalmente de barro, destinadas a oratorios o retablos de las que, por entonces, eran reducidas iglesias parroquiales. La confección de esculturas en barro y madera de dimensiones reducidas, se generalizó en Flandes hacia finales del siglo XV. En el comercio artístico flamenco, Portugal era uno de los principales clientes, sobre todo de las poupées o "vírgenes muñecas" de los talleres de la ciudad de Malinas. Esos modelos llegaron a Brasil y su rigidez será una de las características del arte mariano brasileño hasta el siglo XVIII.

Entre los ejemplos podemos citar la que tradicionalmente se tiene por la ser la más antigua, Nossa Senhora da Conceição de Itanhaém (litoral sur del Estado de São Paulo), datada hacia mediados del siglo XVI. En cualquier caso, no cabe duda de que la fecha de fabricación de la pieza en nada modifica el lenguaje artístico que le es propio. Podríamos citar otros ejemplos en Pernambuco, la magnífica colección del Museu de Arte Sacra da Universidade Federal da Bahia, en Salvador o, sin duda, el acervo del Museu de Arte Sacra de São Paulo. Sin embargo, a pesar de la distancia física entre Salvador y São Paulo, vemos que para los patrocinadores y artistas que trabajaron el arte religioso no hubo diferencias entre los modelos ni se buscó introducir modificaciones o variantes regionales ${ }^{4}$. Un ejemplo artístico de tantos, pero con un significado espiritual profundísimo, es el caso de la Inmaculada que fue encontrada en uno de los márgenes del río Paraíba do Sul (Estado de São Paulo) en 1717, una pieza de barro de pequeño tamaño bajo la advocación de Nossa Senhora Aparecida, que fue reconocida por la bula del papa Pío XI "Principal patrona de todo Brasil" (Marino, 1996: 42), ya citada anteriormente.

La Orden Benedictina fundó sus primeros conventos en Brasil a finales del siglo XVI, siendo el más antiguo el de la entonces capital, Salvador, y más tarde el de Río de Janeiro. Los benedictinos fomentaron la escultura en barro, que tanto éxito alcanzaba en la metrópoli y que conoció un decidido impulso con la creación de una escuela de barristas en torno al monasterio cisterciense de Alcobaça. Además, en la colonia no existían fondos ni capacidad para grandes encargos artísticos, de ahí que muchas de las esculturas de esa centuria sean modestas y muy probablemente impulsadas por los monjes benedictinos artistas o por los artistas con taller propio que para ellos trabajaban. Pero también fomentaron devociones marianas que alcanzarían luego gran prestigio, como la multiplicación de imágenes de Nossa Senhora do Desterro (huída a Egipto) que permitía la confección de grupos con las tres figuras - Virgen, San José y el Niño - y otras dos devociones de especial interés en España: 
Nossa Senhora do Monte-Serrate y Nossa Senhora do Pilar.

Llevamos muchos años investigando esta cuestión y hasta ahora no hemos podido determinar de forma rotunda el porqué del éxito de estas devociones en Brasil. Ahora bien, existe una fuente de información de considerable importancia; se trata del mayor monumento literario escrito sobre el culto a María en el siglo XVIII portugués, titulado Santuário Mariano, debido al enorme esfuerzo compilatorio de relatos sobre las fundaciones de templos dedicados a la Virgen en todo el imperio lusitano. Fue escrito por el fraile agustino frei Agostinho de Santa María (1642-1728), natural de Estremoz (Portugal). Entre 1707 y 1723 se publicaron los diez volúmenes, estando el X (1723) dedicado especialmente a Brasil.

En ese volumen consta la fundación de una capilla dedicada a la Virgen de Montserrat junto al mar, en la zona portuaria de Salvador, por una de las primeras familias hacendadas de Bahía, la Garcia d'Ávila, llegada con el primer gobernador-general de Brasil, Tomé de Sousa en 1549. Poco se sabe del patriarca familiar, pero en función de su nombre, parece ser de origen castellano. Pues bien, sobre esta capilla, Santa María (1723, p. 64) indica lo siguiente:

Este santuario de Nossa Senhora de Monserrate Protectora da Catalunha, fundaraõ os senhores da Torre que chamaõ de Garcia Dias de Avila; os quaes naõ sem superior destino fizeraõ delle doação aos monges do Patriarca São Bento, e como elles saõ devotissimos deste Senhora, e a servem fervorosos em o seu original de Catalunha (...) he de escultura de madeyra estofada, e vesse sobre um trono de serafins, tem sobre o braço esquerdo o Menino Deos, a sua altura saõ quatro palmos.

Aunque la talla actual es posterior, aún se conserva esa devoción entre las más antiguas de Salvador, si bien en la memoria colectiva actual no se relaciona este culto con el catalán.

Más enraizado resultó el culto a la Virgen del Pilar; tampoco sabemos cómo llegó a Brasil en el Seiscientos, aunquesíqueensu difusión participaron

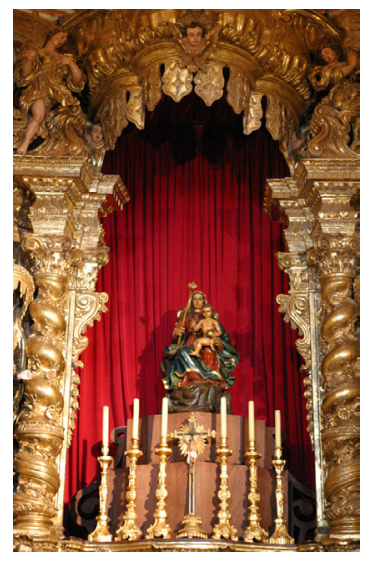

Imagen 5. Nossa Senhora do Monte-Serrate. Anónima. Escultura en talla policromada del siglo XVII. Capilla de Monte-Serrate, Salvador da BahíaSão Paulo.

nuevamente los benedictinos, además de otros sacerdotes seculares y devotos, principalmente del Estado de São Paulo, que en sus expediciones al interior de Minas Gerais, las bandeiras, tomasen esa advocación como santo y seña. Pudo arribar a Brasil alimentada por la tradición piadosa portuguesa del camino de Santiago y el culto al Apóstol. El propio frei Agostinho (1723: 64) señala varios templos fundados en su honor en Salvador, Sergipe o Río de Janeiro; con respecto a su capilla de Salvador indica que los fundadores la mandaron a edificar por las "grandes maravilhas que obrava; não só na sua casa de Sagagoça de Aragam, mas das que obrava na sua cópia que se venera em Lisboa (...)". Dicho de otro modo, que alude al Pilar como una devoción igualmente portuguesa.

Sin embargo, será en Minas Gerais, por influencia del culto tan notable que tenía en Río de Janeiro (monasterio benedictino) donde, curiosamente, la devoción y el número de obras de arte aumentó a lo largo del siglo XVIII. Atraídos por las riquezas auríferas y mineralógicas, se estableció una sociedad plebeya y laica en esa región, formada por bandeirantes que no eran otra cosa de buscadores de oro y piedras preciosas que desde finales del siglo XVII comenzaron a organizar desde São Paulo expediciones, o bandeiras, integradas por colonos y esclavos indígenas para que indicaran los posibles yacimientos. Es curioso, pero por razones que desconocemos, y en las que continuamos trabajando desde la investigación histórica, tenían las bandeiras y los gobernadores coloniales una especial devoción a la Virgen del Pilar zaragozana. Especulamos que la importancia del monasterio 
carioca y el especial cuidado por la talla española, así como el origen nobiliario del culto a Santiago Apóstol, pudiese reforzar en las élites y en los aspirantes a infiltrarse en las redes de poder, una aproximación a la Virgen del Pilar como su especial protectora.

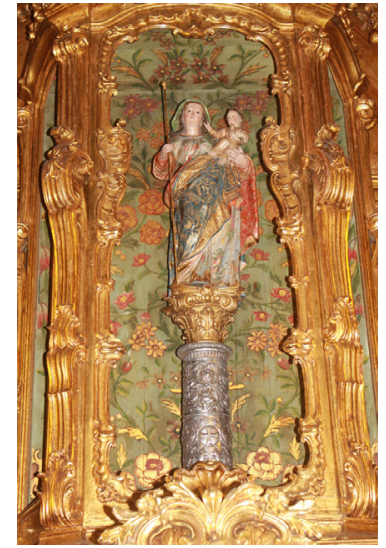

Imagen 6. Nossa Senhora do Pilar. Anónima. Escultura de talla policromada de finales del siglo XVII. Monasterio de São Bento, Río de Janeiro

Augusto de Lima Júnior sugiere, a falta de otras pruebas, que la introducción del culto a la Virgen del Pilar provendría de la región de São João de Rei y Póvoa de Lanhoso, comarca entre los ríos Cávado y Ave, en el norte de Portugal, de donde provendría la familia Chaves que iniciaría, en parte, el poblamiento de la comarca del Rio das Mortes, presidida por la fundación de São João del-Rei, colocada bajo el patrocinio de la Virgen del Pilar (2008: 53). Si bien no deja de ser una hipótesis, y el norte de Portugal, efectivamente, estaba muy influido por el culto al Apóstol y su extensión mariana al Pilar, no parece el argumento definitivo. Una vez más, la ausencia de documentos en un momento tan inicial de la historia de Minas parece dejarnos en una zona gris. Pero eso no debe esconder un hecho que brilla con la luz del sol: en la principal ciudad de Minas, sede de los órganos de gobierno y de la hacienda real, Vila Rica de Ouro Preto, se fundó la parroquia de Nossa Senhora do Pilar, hacia 1712, quedando inaugurado el templo en 1733 con el trasladado del Santísimo desde la cercana iglesia del Rosario de los Negros en una de las más fastuosas celebraciones públicas de la sociedad colonial, descrita con todo primor por el lisboeta y residente de Ouro Preto, Simão Ferreira Machado, en el libro titulado Triunfo Eucharístico, publicado al año siguiente en Lisboa. El autor
(1734: 105) relata con detalles esta procesión en un ejercicio del más cuidado teatro barroco, y sobre el trono de la Virgen señala: "no meyo della se via a ymagem da Senhora, estofada de novo com laborioso primor; com pedras finas embotidas nas mesmas roupas; estas cobertas de ouro até os extremos do Pilar (...)". En realidad, esa fiesta, y otras celebradas en el Brasil colonial, y como sugiere Mary Del Priore, no hacían otra cosa que certificar una identidad propia, porque en ella participaban todos los segmentos de la sociedad, a veces colaborando, a veces como excusa para la consolidación de una élite concreta (2000: 26).

La iconografía del Pilar de Minas Gerais durante todo el siglo XVIII es idéntica a la española, aunque la documentación brasileña de esa centuria no haga mención al templo de Zaragoza ni a su origen; podemos afirmar con seguridad que será la devoción por excelencia de todo el macizo central del Brasil, incluyendo Minas, Goiás y Mato Grosso. Destaca el caso de la catedral de Nossa Senhora do Pilar de São João del-Rei, antes parroquia, que alberga algunas de las más importantes cofradías de Minas $^{5}$. De hecho, la irrupción de este culto supuso su imposición sobre otros anteriores llegados en los momentos fundacionales de la villa de São João. Un documento fechado en 1794 elevado al Conselho Ultramarino de Portugal y dirigido por la Hermandad de Nossa Senhora da Boa Morte de São João del-Rei a la reina Da. María I, buscaba retornar a un estado de privilegios arrebatado por el súbito culto al Pilar. Dice así:

Senhora, a Vossa Magestade por este tribunal deo Conta o Provedor das Capellas de São João de El-Rei, em que refere: que na ygreja de Nossa Senhora do Pillar, Matriz daquela villa de São João del-Rei do Rio das Mortes se venerava desde o seu principio uma devota Ymagem de Nossa Senhora da Boa Morte, cuyo culto corria por conta dos homens pardos congregados em uma mui numerosa Irmandade, erecta havia mais de cincoenta anos com authoridade e approvação do ordinario, a qual tinha com effeito sustentado com decencia, fazendo todos os annos uma solemne e pomposa festividade ${ }^{6}$.

Lo cierto es que ese culto mariano de mulatos 
vinculado a la Pasión no pervivió en la memoria de los sãojoanenses, al menos en la catedral del Pilar, y sí el de la titular. Pero como hemos indicado, esta devoción de origen español se extendió por toda la región interior de Brasil, y en el reparto de feligresías de la capitanía de Goiás, de 1783, apreciamos que entre las diez que contaban con patrocinio mariano, tres eran de la advocación del Pilar ${ }^{7}$.

Por último, queremos hacer mención a la Virgen de Candelaria, originaria de Tenerife, consolidada en la ciudad de Río de Janeiro hacia 1630. Su introducción se debe al matrimonio formado por Antônio Martins da Palma y su mujer, originarios de la isla canaria de La Palma y salvados de un naufragio ante las costas de Río. Al llegar al puerto, en acción de gracias, fundaron una iglesia en su honor, al recordar la imagen más devota de su tierra isleña, un templo que fue luego donado a la Santa Casa de la Misericordia y con el tiempo, convertido en la más importante parroquia carioca. La iglesia, nuevamente construida a finales del siglo XVIII y ricamente decorada durante el siglo XIX, fue enriquecida con una serie de pinturas en la nave del templo por el artista João Zeferino da Costa (18401915), poseedor de estudios académicos y con una sólida estancia formativa en Roma. Regresó a Brasil en 1877 y efectuaría estas pinturas por encargo de la Hermandad de la Candelaria en 1889. Una de ellas nos recuerda la partida de los fundadores desde la isla canaria de La Palma rumbo hacia América del Sur. Este lienzo, junto con los demás que componen el ciclo, muestra la protección de María sobre un español que se arriesgaba en la aventura americana durante las primeras décadas de la historia brasileña (Castro Brunetto, 2010: 7394).

\section{Conclusiones}

Las artes, testigos silenciosos del paso del tiempo, nos revelan la reiteración de modelos marianos, devociones que no adquieren un nuevo sentido iconográfico en Brasil, sino que repiten invariablemente el modelo artístico llegado entre los siglos XVI y XVII. Sí que hay fervor mariano en Brasil, pero un fervor mesurado, adecuado al papel

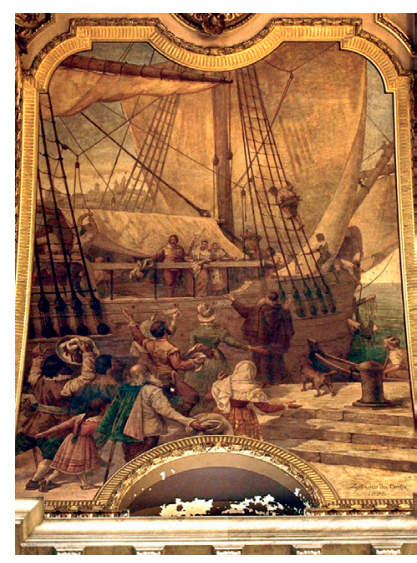

Imagen 7. Partida de Antônio Martins de la isla canaria de La Palma. João Zeferino da Costa, pintura al fresco, 1889. Iglesia de Nossa Senhora da Candelária, Río de Janeiro.Janeiro.

de María en la historia del cristianismo y la liturgia de la Iglesia, sin traspasar, salvo alguna esporádica excepción, los límites de la fe popular. Lo que llama la atención es que esa actitud se produce en una realidad, la iberoamericana (devoción a la Virgen de Guadalupe, en México, por ejemplo), donde Brasil es excepcional. La única explicación sería que Brasil dependía afectiva y devocionalmente de Portugal, no de España e Hispanoamérica. Allí la tendencia a la exacerbación del culto mariano también se fue transformando en una regla habitual, sobre todo desde el siglo XVII, sin que esta mentalidad pasase a la colonia brasileña con tanta intensidad.

La presencia de las devociones españolas en Brasil marcará un hito frente a la tradición portuguesa. Aunque desconozcamos las razones exactas y documentadas que justificasen la influencia española, es indiscutible su intensidad en la historia religiosa y el arte de Minas y otros lugares del Brasil. Quizás sea uno de los puntos de mayor aproximación entre España y Brasil a lo largo de la historia, aunque pase completamente desapercibido. Son ejemplos que no nos hablan: nos gritan desde todos los retablos y las páginas de las fuentes históricas, pero nuestra arraigada ceguera para ver lo que tenemos delante, arrollado por la búsqueda de documentos que, en tal caso, solo confirmarían vagamente lo que ya sabemos, relega el estudio de esta realidad del culto mariano español en Brasil a una cuestión secundaria. Asentar estas ideas requerirá de constantes esfuerzos investigadores en el futuro; en este trabajo nos limitamos a sugerir hipótesis de trabajo con la 
esperanza de que la discusión científica pueda rendir buenos frutos.

Afirmamos, con ánimo de concluir, que el culto a la Virgen María resume la propia historia religiosa de Brasil. A semejanza de Portugal y España, ocupa un espacio central en materia religiosa y el arte es un trasunto de las devociones ibéricas. A diferencia de ellas, los temas de la Pasión ceden su espacio devocional para que reluzca la Virgen como mediadora, según la estricta doctrina de la Iglesia, aunque sin tanta algarabía como acontece entre sus vecinos hispánicos; en cualquier caso, María se muestra como un eslabón crucial para entender la propia identidad del Brasil.

\section{NOTAS}

'Por cuestiones de espacio, tenemos que simplificar excesivamente esa cuestión que es, sin embargo trascendental para la historia brasileña. Para conocer la compleja aproximación entre lusos e indígenas y la importancia del profetismo tupí como forma de resistencia indígena, recomendamos la lectura de la obra de Ronaldo Vainfas (1995: 41-46)

${ }^{2}$ Los datos históricos aquí ofrecidos sobre esta escultura han sido facilitados por el Dr. Percival Tirapeli, Profesor Titular de Historia del Arte de la Universidade Estadual Paulista y forman parte del informe que elevó al Conselho de Defesa do Patrimônio Histórico, Arqueológico, Artístico e Turístico del estado de São Paulo (Condephaat) para su consideración como bien de interés patrimonial, consideración otorgada en 2012

${ }^{3}$ De forma extensa, Francisco González Luis presenta una visión del papel de Anchieta en la evangelización y primera cultura del Brasil (1988: 59-64).

${ }^{4}$ La bibliografía sobre este tema es extensísima y escapa a los objetivos de esta contribución científica. Pese a ello, por ser un estudio que en cierto modo estimuló análisis posteriores sobre este aspecto del arte colonial. A modo de ejemplo citamos el que sigue: (Etzel, 1984: 71-94).

${ }^{5}$ Véase, por ejemplo, las relaciones de las hermandades allí radicadas hacia finales del siglo XVIII. Arquivo Histórico Ultramarino, Lisboa (AHU), Cód. 1.675, fols. 12-12v.

${ }^{6}$ Supplica da Irmandade de Nossa Senhora da Boa Morte de São João del-Rei à Rainha D. Maria I, 30 de abril de 1794. Arquivo do Instituto Histórico e Geográfico Brasileiro, Río de Janeiro (AIHGB), Arq. 1.2.6, fol. 142r.
${ }^{7}$ Relação de freguesias no Estado de Goiás. AIHGB, Arq. 1.2.7. fols. 271-273v.

\section{REFERENCIAS BIBLIOGRÁFICAS}

ANCHIETA， J. (1987). "Poema de María". En: FORNELL, J. M. (ed.). Poema a la Virgen María. Santa Cruz de Tenerife: Gráficas Tenerife.

BAHIENSE, N. (1952). O convento da Penha. Vitória: Escola Técnica de Vitória.

CÂMARA, A. P. (1757). Sermão de Nossa Senhora da Lapa na noite da procissão, que fizeraõ os seus devotos...pelo sucesso de Lisboa... Lisboa: Officina Patriarcal de Francisco Luiz Ameno.

CARO BAROJA, J. (1985). Las formas complejas de la vida religiosa. Religión, sociedad y carácter en la España de los siglos XVI y XVII. Madrid: Sarpe.

CASTRO BRUNETTO, C. J. (1996). Franciscanismo y Arte Barroco en Brasil. Santa Cruz de Tenerife: Asociación Hispánica de Estudios Franciscanos.

CASTRO BRUNETTO, C. J. (2010). "Los fundadores palmeros de la iglesia de la Candelaria de Río de Janeiro en el arte". Revista Estudios Canarios, La Laguna, n LIV. pp. 73-94.

CONCEIÇÃO, A. (1746). Viagem devota, e feliz, dedicada á Imaculda Conceição...em que os navegantes exercendo algumas devoções, e discorrendo em cousas espirituais.... Lisboa: Officina de Jozé António Plates.

DEL PRIORE, M. L. (2000). Festas e utopias no Brasil colonial. São Paulo: Brasiliense.

DENZINGER, E. (1963). El magisterio de la Iglesia. Barcelona: Editorial Herder.

ETZEL, E. (1984). Arte Sacra. Berço da arte brasileira. São Paulo: Editora Melhoramentos.

FADEL, S. (2006). Arte Moderna no Brasil. O olhar do colecionador. Rio de Janeiro: Edições Fadel.

GONÇALVES, F. (1973). Breve ensaio sobre a Iconografia religiosa em Portugal. Lisboa: [s.n.].

GONÇALVES, L. R. (2007). Arte brasileira no século XX. São Paulo: Assocação Brasileira de Críticos de Arte: Imprensa Oficial.

GONZÁLEZ LUIS, F. "Apuntes biográficos del Padre José de Anchieta". (1988). En: GONZÁLEZ LUIS, F. (ed.). José de Anchieta: vida y obra. La Laguna: Excmo. Ayuntamiento de San Cristóbal de La Laguna, 9-131.

LEITE, S. (2004). História da Companhia de Jesus no Brasil. São Paulo: Edições Loyola. 
LIMA Jr., A. (2008). História de Nossa Senhora em Minas Gerais. Belo Horizonte: Autêntica Editora: Editora PUC Minas.

MACHADO, S. F. (1734). Triunfo Eucharistico, exemplar da Christiandade Lusitana. Lisboa Occidental: Officina da Música.

MARINO, J. (1996). Iconografia de Nossa Senhora e dos Santos. São Paulo: Banco Safra-Projeto Cultural.

MARQUES, J. (1991). "Da situação religiosa de Portugal nos finais do século XV à missionação do Brasil". Revista de História, Porto, vol. XI. pp. 45-63.

OLIVEIRA, M. (1994). História Eclesiástica de Portugal. Lisboa: Publicações Europa-América.

PAIVA, J. P. (1997). "A produção escrita". En: PAIVA, José Pedro (ed.). Padre António Vieira, 1608-1697. Catálogo da Exposição. Lisboa: Ministério da Cultura-Biblioteca Nacional. pp. 103-105.

RUBERT, A. (1992). Historia de la Iglesia en Brasil. Madrid: Editorial Mapfre.

SANTA MARIA, A. (1723). Santuário Mariano, e história das milagrosas imagens de Nossa Senhora. Tomo X. Lisboa: Officina de Pedro Galrão.

SEBASTIÁN, S. (1985). Contrarreforma y Barroco. Madrid Alianza Editorial.

SIQUEIRA, M. I. (2004). "El indio y el derecho aplicado en Brasil". En: CASTRO BRUNETTO, Carlos Javier (org). Anchieta y los pueblos indígenas del Brasil. La Laguna: Fundación Canaria Mapfre-Guanarteme: Ayuntamiento de La Laguna. pp. 165-186.

VAINFAS, R. (1995). A Heresía dos Índios: catolicismo e rebeldia no Brasil colônia. São Paulo: Companhia das Letras.

VIOTTI, H. A. (1980). Anchieta, o Apóstolo do Brasil. São Paulo: Edições Loyola. 